logos_i_ethos_2019_2_(50), s. 7-25

DOI: http://dx.doi.org/10.15633/lie.3475

Amadeusz Pala

https://orcid.org/0000-0002-3622-6461

Uniwersytet Papieski Jana Pawła II w Krakowie

\title{
Godność-wolność-miłość: struktura dynamizmu życia osobowego człowieka w ujęciu Karola Wojtyły
}

Wiele podejmowanych przez Karola Wojtyłę prób zrozumienia osobowego statusu człowieka dotyczy w jakieś mierze godności, z jaką bytuje, następnie wolności, dzięki której działa, oraz wreszcie miłości, stanowiącej najwłaściwszą treść czynu osoby. Celem niniejszego artykułu jest ukazanie specyfiki relacji zachodzących między godnością, wolnością i miłością jako fundamentu antropologii adekwatnej Wojtyły, warunkującego przebieg i ocenę moralną dynamizmu życia osobowego człowieka ${ }^{1}$.

\section{Godność fundamentem wolności}

W antropologii adekwatnej Wojtyły człowiek na mocy swojego osobowego istnienia ma szczególną godność. Jest to godność ontyczna, a więc całkowicie nieutracalna: ani sama osoba nie może się jej pozbyć, ani też nikt inny nie może jej w żaden sposób osobie odebrać. Godność

1 W niniejszym artykule wykorzystałem fragmenty mojej rozprawy doktorskiej pt. Dynamizm człowieka w ujęciu filozoficznym Karola Wojtyły i Józefa Tischnera obronionej w 2018 roku na Wydziale Filozoficznym Uniwersytetu Papieskiego Jana Pawła II w Krakowie. 
ta nie jest więc w ścisłym sensie czymś, co osoba „posiada”, nie jest cechą, którą można nabyć czy stracić, nie jest czymś przypadłościowym. Godność ta, będąc związana z samym istnieniem człowieka-osoby, jest również tym, co wyraża wartość całego bytu cielesno-duchowego, jego doskonałość jako bytu o naturze rozumnej. Znaczy to, że godność osoby jako wartość nie jest podobna do innych wartości, które osoba posiada, takich jak wartości witalne, estetyczne, czy nawet intelektualne i moralne. Wojtyła pisze: „Wartość samej osoby należy wyraźnie odróżnić od różnych wartości, które tkwią w osobie. Są to wartości wrodzone lub nabyte"2. Zachodzi więc tu szczególna relacja, w której godność osoby jako wartość jest nadrzędna w stosunku do innych wartości, posiadanych przez osobę. Relację tę ciekawie komentuje współczesny polski personalista Tadeusz Biesaga, pisząc: „Godność wskazuje, że osoba jest wartością wartości, a nie odwrotnie, jakoby pewne wartości w osobie stanowiły o jej osobowej godności”3. I nawet jeżeli zazwyczaj te inne wartości tkwiące w osobie narzucają się w sposób bardziej pierwszoplanowy, wprost poprzez doznawanie wrażeń, a także wywołując określone reakcje, przeżycia emocjonalne, to w konsekwencji taka sytuacja nie sprawia jeszcze, że wartość samej osoby, którą ujmuje się inaczej, bo w sposób intuicyjny, umysłowy, staje się istotnie wartością drugoplanową ${ }^{4}$. Jest ona bowiem zawsze wartością centralną, a najbardziej świadczy o tym sytuacja zagrożenia, w której próbuje się ją podważyć, odebrać. Rodzi ona wtedy poczucie wstydu $z$ tego powodu, a co za tym idzie również przeżycie winy - i w takiej właśnie sytuacji człowiek najlepiej pojmuje, że wszystkie inne wartości są w jej obliczu istotnie drugoplanowe ${ }^{5}$. A zatem godność osoby w stosunku do innych wartości tkwiących w osobie jest często jedynie poznawczo drugoplanowa, ale zarówno ontologicznie, jak i aksjologicznie jest zawsze pierwszoplanowa.

${ }^{2}$ K. Wojtyła, Miłość i odpowiedzialność, Lublin 2001, s. 110.

3 T. Biesaga, Godność a wolność w antropologii Karola Wojtyły, w: Ku rozumieniu godności człowieka, red. G. Hołub, P. Duchliński, Kraków 2008, s. 68 (Studia z Bioetyki, 4).

4 Por. T. Biesaga, Godność a wolność w antropologii Karola Wojtyly, dz. cyt., s. 68.

5 Por. A. Szostek, Wolność - prawda - sumienie, „Ethos” 4 (1991) nr 15/16, s. 32-33. 
Godność osoby wyznacza pole aksjologiczne dla wolności. Dzieje się tak dlatego, że godność jest wyrazem prawdy o tym, że istnienie owego konkretnego i realnego bytu człowieka-osoby stanowi zarazem swoiste dobro. Warto bowiem zaznaczyć, że Wojtyle bliskie było tomistyczne związanie aktualnego istnienia $\mathrm{z}$ dobrem ${ }^{6}$. Ponieważ w tym ujęciu o dobru danego bytu decyduje jego natura, istnienie człowieka jako istoty o naturze rozumnej stanowi większe dobro niż istnienie wielu innych bytów, które nie są rozumne. W konsekwencji obiektywna prawda o tym dobru, o godności będącej jego wyrazem, konstytuuje normatywność i kategoryczność powinności moralnej ${ }^{7}$. Wojtyła pisze: „Istotną racją wyboru oraz samej zdolności wybierania nie może być nic innego, jak swoiste odniesienie do prawdy, które wnika w intencjonalność chcenia i tworzy jakby jego zasadę wewnętrzną"8. Dlatego trzeba stwierdzić, że prawda o godności wynikającej z natury osoby wyznacza wolności to dobro, które w trakcie spełniania czynu powinno zostać realizowane - godność osoby wyznacza wolności, co jest godne; a nie odwrotnie, to nie akt wolności decyduje o godności osoby. Wojtyła powiada: „Godność człowieka, godność osoby nie może polegać na byle jakim użyciu wolności, nie może polegać na wolności użycia. [...] Godność człowieka może tylko polegać na prawym, na odpowiedzialnym użyciu ludzkiej wolności"9.

\section{Godność rodzi powinność}

Problem godności jest nierozerwalnie związany z kwestią powinności moralnej. O powinności informuje nas przeżycie „chcę” wyrastające z przeżycia „powinienem”. Tym, czego osoba chce, a zarazem co powinna, jest pełnienie dobra i stawanie się dobrą pod względem moralnym, stąd

6 Por. K. Wojtyła, Dobro i wartość, w: Wykłady lubelskie, red. T. Styczeń, W. Chudy, J. W. Gałkowski, A. Rodziński, A. Szostek, Lublin 2006, s. 142.

7 Por. T. Biesaga, Godność a wolność w antropologii Karola Wojtyły, dz. cyt., s. 72.

${ }^{8}$ K. Wojtyła, Osoba i czyn, w: „Osoba i czyn” oraz inne studia antropologiczne, red. T. Styczeń, W. Chudy, J. W. Gałkowski, A. Rodziński, A. Szostek, Lublin 2000, s. 181.

9 K. Wojtyła, Znak, któremu sprzeciwiać się będą, Kraków 2005, s. 133. 
o powinności moralnej trzeba mówić w kategoriach przeżycia „chcę być dobry”, które rodzi się w człowieku dzięki przeżyciu dobra moralnego. Ważną funkcję pełni tu rozum, który poznaje wartości moralne. To on przedstawia osobie zasady postępowania, których wypełnianie prowadzi do jej doskonalenia pod względem moralnym. Przede wszystkim jednak powinność rodzi się za sprawą godności, jaką ma każdy byt osobowy, który będąc dobry z natury, dąży przez naturalne nastawienie woli, do realizacji tego, co dobre ${ }^{10}$. Wojtyła uważa, że przeżycie powinności jest doznawane w sposób spontaniczny i oczywisty, ponieważ rzeczywistość moralna istnieje obiektywnie, stąd czynnik subiektywny w postaci prywatnych przekonań o sensie życia nie może negować występowania przeżycia powinności (co najwyżej może być ono do pewnego stopnia zakłócone lub niedojrzałe). Ponieważ normy etyczne istnieją w sposób obiektywny, człowiek nie może ich tworzyć, ale jedynie odczytywać i to właśnie rodzi przeżycie powinności moralnej ${ }^{11}$. Owo obiektywne istnienie rzeczywistości moralnej sprawia, że człowiek naprawdę staje się dobry lub zły, w zależności od tego, jaką kwalifikację moralną ma jego czyn $^{12}$.

Powyższe poglądy mają duże znaczenie dla antropologii adekwatnej Wojtyły. Jest w nich obecne przekonanie, że niezależnie od kultury, w jakiej człowiek się wychował, niezależnie od poglądów, jakie w sobie wykształcił, dzięki swojej rozumnej naturze może rozpoznać obiektywne normy moralne, a także swoją osobową godność, która motywuje go do spełniania tych norm - a to wszystko przyjmuje postać przeżycia powinności moralnej. Co więcej, powinność ta nie odbiera człowiekowi wolności, ponieważ nie zmusza go do realizacji określnych wartości,

10 Por. K. Wojtyła, Elementarz etyczny, Lublin 1999, s. 43.

11 „Etyka chrześcijańska utrzymuje, że normy moralne, podobnie jak wszystkie prawa natury stworzonej, pochodzą od Stwórcy, jednakże sposób pochodzenia olbrzymiej większości tych norm jest naturalny; człowiek uświadamia je sobie po prostu rozumem" (K. Wojtyła, Elementarz etyczny, dz. cyt., s. 26).

12 Por. M. Jałocho-Palicka, Dobro i zło $w$ dramacie poznania (W kręgu inspiracji Karola WojtyłyJana Pawła II), „Scripta Philosophica. Zeszyty naukowe doktorantów Wydziału Filozofii KUL” 2 (2013), s. 74. 
a jedynie wskazuje, które z nich przyczynią się do tego, by cała jego osobowa struktura, a więc także jego wolność, była realizowana na miarę godności, jaką stanowi. Wojtyła powiada: „Wolność woli ludzkiej bowiem najpełniej uwydatnia się w moralności przez powinność. Powinność zaś wyrasta zawsze w zetknięciu woli z jakąś normą" ${ }^{13}$. A zatem powinność moralna nie tyle przeczy wolności, ile raczej pokazuje, jak tę wolność zachować czy nawet wzmocnić - Wojtyła przyjmuje bowiem koncepcję tak zwanego ideału etycznego, który jest wzorem osobowej samorealizacji, wzorem godnym naśladowania. Osoba podejmująca wysiłek realizacji dobra może upodabniać się do tego wzoru, a dążenie to staje się dla niej szczególnego rodzaju powinnością moralną ${ }^{14}$. Warto dodać, że tym, co przestrzega przed zburzeniem owej naturalnej relacji zachodzącej między godnością a wolnością, jest sumienie.

\section{Wolność jako samozależność}

Wojtyła, badając wolność, zastanawia się głównie, jak człowiek ją przeżywa. Jego analizy fenomenologiczne pokazują, że wolność przejawia się w doświadczeniu sprawczości, a dokładnie w przeżyciu „chcę”, którego źródłem jest akt wolnej woli. Przeżycie „chcę” ulokowane jest między członami przeżycia „moge - nie muszę"15. Wojtyła powiada, że przeżycie to zawiera "tendencję determinacyjną" ", co wcale nie oznacza, że jest to dążenie, które nie jest wolne (jakby było absolutnie zdeterminowane przez jakiś czynnik), wręcz przeciwnie, chodzi o to, że jest skonkretyzowane, to znaczy nakierowane na określony cel oraz umotywowane, czyli poprzedzone swoistym rachunkiem motywów - wyborem jednych wartości kosztem innych, ponieważ każdy wybór jest zarazem pewnym

13 K. Wojtyła, Miłość i odpowiedzialność, dz. cyt., s. 107.

14 Por. K. Wojtyła, Ewangeliczna zasada naśladowania. Nauka źródet objawienia a system filozoficzny Maxa Schelera, w: Zagadnienie podmiotu moralności, red. T. Styczeń, J. W. Gałkowski, A. Rodziński, A. Szostek, Lublin 2001, s. 151-153.

15 Por. K. Wojtyła, Zagadnienie woli w analizie aktu etycznego, w: Zagadnienie podmiotu moralności, dz. cyt., s. 187-193.

16 K. Wojtyła, Akt i przeżycie etyczne, w: Wykłady lubelskie, dz. cyt., s. 35. 
odrzuceniem tego, co nie zostało wybrane. Wojtyła pisze: „Wybór jest zawsze pozostawieniem innych przedmiotów czy też innych wartości możliwych na rzecz jednego przedmiotu, jednej wartości. Jest on też odsunięciem innych chcen potencjalnych na rzecz jednego aktualnego" ${ }^{17}$. Innymi słowy, owa „tendencja determinacyjna” oznacza, że wolność nie jest zdeterminowana w sposób negatywny (ograniczający), ale w sposób pozytywny (nadający sens poprzez wybór tego, co dobre). Spełnienie wolności dokonuje się bowiem jedynie wtedy, gdy jest zależna od prawdy, czyli nie realizuje się ona "przez podporządkowanie sobie prawdy, ale przez podporządkowanie się prawdzie" ${ }^{18}$. Przywołując wcześniejsze rozważania, warto powtórzyć, że prawdą, od której wolność w pierwszej kolejności jest zależna, jest prawda o dobru, jakie stanowi człowiek, a więc prawda o jego godności.

Zdaniem Wojtyły element wolności związany jest $\mathrm{z}$ dynamiczną strukturą człowieka. Bez wolności nie byłoby możliwe realizowanie wartości moralnych w czynie, a co za tym idzie, stawanie się coraz bardziej „kimś" pod względem moralnym. Stąd też wartości moralne nie realizują się $\mathrm{w}$ ramach tak zwanych uczynnień, a więc w sferze „dziania się czegoś w człowieku”, gdzie wolność nie występuje. Obecność owego momentu wolności ujawnia się dopiero w doświadczeniu czynu, w sferze działania człowieka ${ }^{19}$. Można też powiedzieć, że owa dynamika wolnego działania człowieka wyznacza w sposób szczególny „to, co nieredukowalne" w człowieku. Dlatego też wolność jest tym, co wyróżnia człowieka w świecie przyrody - Wojtyła powiada: „wolność [...] świadczy, że nie jest on jakąś choćby szczytową organizacją materii ożywionej, ale jakimś «ustrojem» całkowicie odrębnym" ${ }^{20}$.

Zdaniem Wojtyły wolność to inaczej samostanowienie, będące dynamizmem ludzkiej woli, która to wedle przyjętej przez niego tradycji arystotelesowsko-tomistycznej jest integralnym elementem bytu

17 K. Wojtyła, Osoba i czyn, dz. cyt., s. 176.

18 K. Wojtyła, Osoba i czyn, dz. cyt., s. 198.

19 Por. J. Galarowicz, Imię własne człowieka. Klucz do myśli i nauczania Karola Wojtyły - Jana Pawła II, dz. cyt., s. 126.

20 K. Wojtyła, Rozważania o istocie człowieka, Kraków 1999, s. 68-69. 
człowieka-osoby, władzą jego duszy ${ }^{21}$. Ale chociaż wola jest z natury związana $z$ wolnością, to istnieje między nimi zasadnicza różnica: mianowicie wola jest jedynie czymś przypadłościowym względem bytu człowieka, natomiast wolność będąca istotą samostanowienia jest elementem substancjalnego wymiaru owego bytu ${ }^{22}$. Istotną kwestią dotyczącą funkcjonowania woli jest to, że: „akt woli zawsze jest poprzedzony aktem poznania [...]. To poznanie nie jest teoretyczne, ale wartościujące, tzn. bierze wzgląd nie tyle na istotę przedmiotu, ile na dobro przedmiotu. Taki kierunek poznania wynikać może tylko ze ścisłego współdziałania rozumu i woli. Rozum dlatego wartościuje, bo jest niejako przeniknięty do głębi właściwą woli dążnością, pędem do dobra. Ten wzgląd na dobro jako na cel ujawnia wolę i jej wpływ w poszczególnych aktach człowieka"23. Akt poznania dostarcza zatem woli sądu dotyczącego przedmiotu jej pożądania, a co za tym idzie, wartości moralnej, jaką niesie realizacja danego czynu - dzięki temu człowiek może dokonać wyboru o charakterze moralnym, realizując dobro lub zło $^{24}$. Wojtyła pojmuje zatem wolę w sposób dwojaki: $\mathrm{z}$ jednej strony jest ona niezależna w dziedzinie intencjonalnej, poznawczej (co umożliwia jej skierowanie ku różnym przedmiotom chcenia), z drugiej zaś strony jest zależna od ,ja” osoby - każdy bowiem wybór jest wyborem dokonywanym przez konkretną osobę. A owo zakorzenienie aktu chcenia danego przedmiotu w osobie jako podmiocie tego aktu nazywa on „zależnością w prawdzie" 25 . Wojtyła powie, że ma tu miejsce sytuacja, w której: „Wolność w znaczeniu podstawowym to tyle, co samozależność. Wolność w znaczeniu rozwiniętym to niezależność w dziedzinie intencjonalnej”26. Co istotne, takie rozumienie wolności nie prowadzi do antynomii, ponieważ zależność z jednej strony i niezależność z drugiej są realizowane

21 Por. K. Wojtyła, Zagadnienie woli w analizie aktu etycznego, dz. cyt., s. 193-194.

${ }^{22} \mathrm{~K}$. Wojtyła, Osobowa struktura samostanowienia, w: „Osoba i czyn” oraz inne studia antropologiczne, dz. cyt., s. 426-427.

${ }^{23}$ K. Wojtyła, Rozważania o istocie człowieka, dz. cyt., s. 65-66.

${ }^{24}$ K. Wojtyła, Osoba i czyn, dz. cyt., s. 182-184.

25 K. Wojtyła, Osoba i czyn, dz. cyt., s. 182.

26 K. Wojtyła, Osoba i czyn, dz. cyt., s. 183. 
na różnych poziomach: osoba jest wolna, czyli niezależna od czynników zewnętrznych, ale zależna od własnego wnętrza, od osobowego „ja” dzięki czemu jej wolność nie jest jakąś samowolą, lecz właśnie samozależnością. W tym sensie trzeba stwierdzić, że owa koncepcja wolności nie wpisuje się ani $\mathrm{w}$ determinizm, ani $\mathrm{w}$ indeterminizm, ale stanowi swoistą postać autodeterminizmu ${ }^{27}$.

Wolność w antropologii adekwatnej Wojtyły występuje jako „wolność człowieka, a nie tylko wolność woli w człowieku - chociaż niewątpliwie wolność człowieka poprzez wolę"28. Wojtyła jest przekonany, że nie należy pojmować wolności w sposób wąski, jedynie jako czegoś, co umożliwia wybór, co jakby tylko „uwalnia” wolę, lecz należy ją rozumieć o wiele szerzej i głębiej - chodzi bowiem przede wszystkim o wolność człowieka w ogóle, a ta nie polega tylko na tym, że może on coś wybrać lub nie, ale przede wszystkim na tym, że przez owe wolne wybory, przez samostanowienie o sobie, może sam być w stosunku do siebie wolny. Takie całościowe rozumienie wolności jako samostanowienia pozwala Wojtyle na wyakcentowanie szczególnej struktury człowieka-osoby: „Oto bowiem ta sprawczość, która jest zarazem samostanowieniem, odsłania nam w całości osobę jako podmiotową strukturę samo-panowania i samo-posiadania”29. Dokładniej mówiąc, w przeżyciu odsłania się „cała osobowa struktura samostanowienia, w której człowiek odnajduje swoje «ja» jako tego, który siebie posiada i sobie panuje - a w każdym razie może i powinien siebie posiadać i sobie panować. [...] Równocześnie bowiem struktura ta jest całkowicie wewnętrzna, immanentna, stanowi rzeczywiste wyposażenie podmiotu osobowego, poniekąd jest nim samym. W przeżyciu samo-posiadania i samo-panowania człowiek przeżywa to, że jest osobą, i to, że jest podmiotem"30. Trzeba też zauważyć,

27 Por. J. Galarowicz, Imię własne człowieka. Klucz do myśli i nauczania Karola Wojtyły - Jana Pawła II, dz. cyt., s. 129.

28 Por. K. Wojtyła, Osobowa struktura samostanowienia, dz. cyt., s. 427.

29 K. Wojtyła, Osoba: podmiot $i$ wspólnota, w: „Osoba i czyn” oraz inne studia antropologiczne, dz. cyt., s. 385 .

${ }^{30}$ K. Wojtyła, Podmiotowość $i$,to, co nieredukowalne” w człowieku, w: „Osoba i czyn” oraz inne studia antropologiczne, dz. cyt., s. 441. 
że owa struktura samo-panowania i samo-posiadania wyznacza szczególny zwrot podmiotu ku sobie samemu, dzięki któremu podmiot dokonuje swoistego samospełnienia ${ }^{31}$. Struktura ta świadczy o szczególnym wymiarze dynamizmu życia osobowego człowieka, który to człowiek jest zarazem tym, kto siebie posiada i jest przez siebie posiadany, kto sobie panuje i podlega swojemu panowaniu. Oznacza to w konsekwencji, że byt człowieka-osoby jest nieprzekazywalny, nieodstępowalny, że nie może być posiadany przez kogoś innego - owa niemoc stanowi zatem granicę ludzkiej wolności. Wojtyła powiada: „Z natury, czyli z racji tego, jakim jest bytem, osoba jest panem siebie samej (sui iuris) i nie może być odstąpiona innej ani też zastąpiona przez inną $\mathrm{w}$ tym, co domaga się udziału jej własnej woli i zaangażowania jej osobowej wolności (alteri incommunicabilis)"32. Co istotne jeszcze, owa nieprzekazywalność osoby, o której świadczy struktura samo-panowania i samo-posiadania, nie jest czymś, co by sprawiało jakieś zamknięcie się osoby w sobie samej. Autor Osoby i czynu wyjaśnia: „Wręcz przeciwnie, zarówno samo-posiadanie, jak też i samo-panowanie oznacza szczególną dyspozycję do «daru z siebie samego», i to właśnie daru «bezinteresownego». Tylko ten mianowicie, kto sam siebie posiada, może też siebie samego oddać - i to oddać bezinteresownie. I tylko ten, kto sobie samemu panuje, może też z siebie samego uczynić dar, i to znowu dar bezinteresowny" ${ }^{33}$.

\section{Odpowiedzialna wolność jest dla miłości}

Człowiek jako wolny może czynić dobro lub zło, jednak takie doświadczenie sprawczości czynu jest nie tylko doświadczeniem swojej wolności $\mathrm{w}$ jego spełnianiu, ale również doświadczeniem odpowiedzialności za jego spełnienie. I dlatego można również powiedzieć, że jeżeli wolność jest warunkiem sprawczości osoby w czynie, to sprawczość (a więc pośrednio i wolność) jest warunkiem odpowiedzialności

31 Por. K. Wojtyła, Osoba i czyn, dz. cyt., s. 196.

32 K. Wojtyła, Miłość i odpowiedzialność, dz. cyt., s. 112.

33 K. Wojtyła, Osoba i czyn, dz. cyt., s. 431. 
za czyn $^{34}$. Wojtyła podkreśla zatem konieczność występowania tych dwóch elementów jednocześnie: wolności i odpowiedzialności. Innymi słowy, jeżeli człowiek nie działałby w sposób wolny, to nie byłby za nic odpowiedzialny, a zarazem człowiek nie może nie być odpowiedzialny za jakiekolwiek swoje wolne działanie ${ }^{35}$. Wojtyła pisze: „Świadomość, że spełniam dany czyn, że jestem jego sprawcą, niesie z sobą poczucie odpowiedzialności za wartość moralną tego czynu. Przeżywam tedy siebie samego, moją własną osobę, jako przyczynę sprawczą dobra lub zła moralnego w określonym czynie, a przez to przeżywam dobro lub zło moralne mojej własnej osoby"36. A zatem przyjęcie w życiu postawy odpowiedzialnej prowadzi do rozwoju moralnego swojej osoby.

Zdaniem Wojtyły, aby postępować odpowiedzialnie, należy przede wszystkim wykorzystać wolność dla miłości, która to bez wolności nie jest w ogóle możliwa. Poprzez akt miłości bowiem człowiek najwłaściwiej wykorzystuje swoją wolność, a przez to dowiaduje się, po co właściwie jest wolny, jaki jest sens jego wolności. Inaczej mówiąc, miłość jest najbardziej pożądaną treścią, jaką może wypełnić się wolne działanie człowieka. Mimo że na pierwszy rzut oka pod wpływem miłości wolność człowieka zostaje niejako ograniczona (ze względu na dokonany wybór, który zawsze jest zarazem odrzuceniem tego, co nie zostało wybrane), jednak ograniczenie to wcale nie jest czymś negatywnym. Wręcz przeciwnie - czymś nadzwyczaj twórczym, ponieważ dynamizuje wolność człowieka w ten sposób, że człowiek staje się coraz bardziej dojrzały zyskuje większą pewność co do tego, co tak naprawdę warto wybierać. Trzeba więc koniecznie zauważyć, że obok wcześniej już wspomnianego dynamizowania woli przez wolność (co jest wyrażane pojęciem „wolnej woli w człowieku”), występuje tu drugi rodzaj dynamizowania: miłość dynamizuje „wolność człowieka jako takiego” - dlatego można powiedzieć, że dzięki spełnianiu czynów polegających na miłości człowiek

34 Por. K. Wojtyła, Osoba i czyn, dz. cyt., s. 222.

35 Por. J. Galarowicz, Imię własne człowieka. Klucz do myśli i nauczania Karola Wojtyły - Jana Pawła II, dz. cyt., s. 153.

${ }^{36}$ K. Wojtyła, Problem oderwania przeżycia od aktu w etyce na tle poglądów Kanta i Schelera, w: Zagadnienie podmiotu moralności, dz. cyt., s. 161. 
jako osoba staje się coraz bardziej wolny. To stawanie się coraz bardziej wolnym nie ma więc znaczenia poszerzenia wolności woli w człowie$\mathrm{ku}$ (ona pozostaje nienaruszona), lecz raczej wzmocnienia skłonności do wybierania prawdziwego dobra (czy też upodobania w dobru). Jest to więc stawanie się coraz bardziej wolnym człowiekiem, coraz bardziej wolnym od skłonności do wyboru zła (od upodobania w złu). Oczywiście takie wzmacnianie wolności człowieka nigdy nie sprawi całkowitego odcięcia się od możliwości wyboru zła. Miłość jedynie umacnia strukturę wolności człowieka, strukturę jego samo-panowania i samo-posiadania (co oznacza też stawanie się coraz bardziej cnotliwym). Takie umacnianie wymaga jednak ciągłej pracy nad sobą - jest zadaniem, które należy nieustannie realizować. W tym sensie dla Wojtyły wolność nie jest tylko czymś danym (jak wolność woli w człowieku), ale przede wszystkim jest czymś zadanym: jest zadanym ideałem wolności, czy inaczej pożądanym stanem człowieka-osoby, wykluczającym jego moralne zniewolenie. Pisze on: „O dojrzałości osoby, o jej doskonałości, stanowi w zasadniczej mierze to, że pozwala się ona pociągnąć prawdziwym wartościom, że pozwala im się bez reszty wciągnąć i jakby zaabsorbować” ${ }^{37}$. Osoba, rozpoznając dobro, jakie stanowi druga osoba, i kochając ją, może uczestniczyć w tym dobru poprzez miłość do tej osoby ${ }^{38}$. Wolność, umożliwiając akt miłości, napełnia wolę dobrem, którego z natury wola szuka. Warto też podkreślić, że wolność nie jest w tej sytuacji czymś absolutnym, nie jest celem, ale jest środkiem do celu: ponieważ właśnie to dzięki niej człowiek może wybrać prawdziwe dobro jako cel. Dla Wojtyły relacja wolność-miłość polega więc na tym, że wolność jest swoistą drogą miłości, ponieważ tę miłość umożliwia ${ }^{39}$, miłość zaś nadaje sens owej wolności - w miłości spełnia się wolność.

37 K. Wojtyła, Osoba i czyn, dz. cyt., s. 173.

38 K. Wojtyła, Miłość i odpowiedzialność, dz. cyt., s. 120-123.

39 Karol Wojtyła jako Jan Paweł II wyraził to w krótkim stwierdzeniu: „Wolność jest dla miłości” (Jan Paweł II, Pamięć i tożsamość. Rozmowy na przełomie tysiącleci, Kraków 2005, s. 48). 


\section{Miłość przeciwieństwem instrumentalizacji}

Koncepcja miłości zajmuje ważne miejsce w etyce Wojtyły. Duże znaczenie dla jej powstania miała jego polemika z Maxem Schelerem, a także częściowo z Immanuelem Kantem. Wojtyła nie zgadza się bowiem na proponowane przez tych myślicieli dwa skrajne ujęcia miłości. Po pierwsze nie zgadza się na interpretację proschelerowską, która redukuje miłość do przeżywania wartości, a następnie odpowiadania na nie w sposób wyłącznie emocjonalno-poznawczy. Zaś po drugie odrzuca interpretację prokantowską, polegającą na akcentowaniu w miłości wyłącznie aspektu wolicjonalno-powinnościowego. Jego bowiem zdaniem obie te interpretacje brane oddzielnie są nie tyle zupełnie błędne, co niewystarczające - należy je zatem wzajemnie uzgodnić, a więc połączyć przeżycie wartości z przeżyciem powinności ${ }^{40}$.

Warto dodać, że interpretując Schelerowską koncepcję miłości, Wojtyła bierze z niej przede wszystkim dwa elementy: to, że miłość jest otwartością i wrażliwością człowieka na wartości (wrażliwością, która nie może powstać za sprawą samego aktu woli), oraz to, że miłość jest formą emocjonalnego przeżywania wartości ${ }^{41}$. $Z$ kolei etyka Kanta zainspirowała Wojtyłę do głębszego namysłu nad kwestią godności człowieka, na którą jedyną adekwatną odpowiedzią jest miłość, a nie najszczytniejsza nawet postać wykorzystania czy użycia. W efekcie krakowski myśliciel tworzy tak zwaną normę personalistyczną ${ }^{42}$, będącą przeformułowaną i wzbogaconą wersją kantowskiego imperatywu kategorycznego ${ }^{43}$.

A zatem według Wojtyły istota miłości polega na tym, że ma ona wymiar interpersonalnej i realnej relacji, w której chodzi o dobro. Powiada

40 Por. J. Galarowicz, Paradoks egzystencji etycznej, Kraków 2009, s. 180.

${ }^{41}$ Por. J. Galarowicz, Paradoks egzystencji etycznej, dz. cyt., s. 180.

42 „Ilekroć w twoim postępowaniu osoba jest przedmiotem działania, tylekroć pamiętaj, że nie możesz jej traktować tylko jako środka do celu, jako narzędzia, ale liczyć się z tym, że ona sama ma lub bodaj powinna mieć swój cel" (K. Wojtyła, Miłość i odpowiedzialność, dz. cyt., s. 30).

43 „Postępuj tak, byś człowieczeństwa tak w twej osobie, jak też w osobie każdego innego używał zawsze zarazem jako celu, nigdy tylko jako środka" (I. Kant, Uzasadnienie metafizyki moralności, Kęty 2017, p. 429, s. 46). 
on: „miłość jest zawsze jakimś wzajemnym odniesieniem osób. To z kolei oparte jest znów na pewnym stosunku do dobra"44. Relacja ta zakłada zarówno element poznawczy polegający na odkryciu w drugim człowieku osoby, czyli istoty rozumnej i wolnej, podobnej do mnie samego, jak i element przeżywania wartości tej osoby, jej godności ${ }^{45}$. Godność ta wymaga od nas szczególnego rodzaju ustosunkowania się, dania adekwatnej odpowiedzi na nią - a odpowiedź tę określa właśnie norma personalistyczna, wedle której osoba nie może być przedmiotem samego użycia, ponieważ: „osoba jest takim dobrem, że właściwe i pełnowartościowe odniesienie do niej stanowi tylko miłość" ${ }^{46}$.

Nikt więc nie ma prawa dokonać instrumentalizacji osoby, nawet Bóg-Stwórca. Wojtyła pisze o tym bardzo jasno: „nikt nie może posługiwać się osobą jako środkiem do celu; ani człowiek, ani nawet Bóg-Stwórca. Właśnie ze strony Boga jest to najzupełniej wykluczone, gdyż On, dając osobie naturę rozumną i wolną, przez samo to już zdecydował, że będzie ona sama sobie określała cele działania"47. Taki porządek, w którym szanuje się osobę jako wolną istotę, nie czyniąc z niej środka do celu, jest prawdziwym porządkiem moralnym uwzględniającym jej godność. Trzeba zatem powiedzieć, że przeciwieństwem instrumentalnego wykorzystania osoby jest właśnie miłość, której rdzeń to jednocząca od wewnątrz więź. Ta więź jest wynikiem obrania przez osoby wspólnego celu, wspólnego dobra, co stawia je na równi względem siebie, a w efekcie wyklucza podporządkowanie, czyli wzajemną instrumentalizację. Wojtyła pisze: „Uczestnictwo [...] w grupach, które łączy doraźna wspólnota działania, nie przejawia się i nie urzeczywistnia w takiej mierze, jak we wspólnotach, którym odpowiada stałość na gruncie samego bytowania - jak np. we wspólnocie rodzinnej, narodowej, religijnej czy państwowej. Aksjologia takich wspólnot, która wyraża się w dobru wspólnym, jest o wiele głębsza" ${ }^{48}$. Człowiek ciągle będzie się

\footnotetext{
44 K. Wojtyła, Miłość i odpowiedzialność, dz. cyt., s. 69.

45 Por. J. Galarowicz, Paradoks egzystencji etycznej, dz. cyt., s. 181.

46 K. Wojtyła, Miłość i odpowiedzialność, dz. cyt., s. 42.

${ }^{47}$ K. Wojtyła, Miłość i odpowiedzialność, dz. cyt., s. 29-30.

48 K. Wojtyła, Osoba i czyn, dz. cyt., s. 321-322.
} 
uczył miłości, ponieważ ona nie jest czymś gotowym, jest po części ideą wyznaczającą kierunek doskonalenia. Od tego, czy osoby będą dążyć do obiektywnej celowości ich relacji, zależy poziom ich miłości między nimi, a więc i wykluczenie traktowania się jako środków do celu. Dążenie do obiektywnego, wspólnego celu wyznacza prawdziwą miłość ${ }^{49}$.

\section{Odpowiedzialna miłość afirmacją godności}

Akt miłości jednej osoby do drugiej, podmiotu do przedmiotu wywołuje dwojakie skutki. Z jednej strony zmienia się przedmiot tej relacji, jakim jest osoba darzona miłością, która staje się teraz osobą przez kogoś zauważoną, docenioną i chcianą. Z drugiej strony zachodzi zmiana w podmiocie, jakim jest osoba darząca miłością - staje się ona bardziej doskonała pod względem moralnym. Oczywiście rodzaj tej miłości może być różny. I choć Wojtyła skupia się raczej na miłości między kobietą a mężczyzną (miłość oblubieńcza) ${ }^{50}$, to jego koncepcja mieści w sobie również inne odcienie miłości. Niezależnie bowiem od rodzajów miłości sama jej istota jest zawsze taka sama, a jest nią afirmacja godności drugiej osoby ${ }^{51}$. I znowu, afirmacja ta może przybierać różne postacie, w zależności od rodzaju miłości, ale w podstawowym i wystarczającym sensie afirmacja ta oznacza elementarny szacunek dla każdego istnienia ludzkiego. Taka wzajemna miłość jest najlepszym spoiwem dla wszelkich społeczności, czyli większych wspólnot ludzkich, które są tworzone dzięki relacjom międzypodmiotowym.

49 Por. K. Wojtyła, Miłość i odpowiedzialność, dz. cyt., s. 30-33.

50 „Oddanie oblubieńcze jest oddaniem indywidualnym mężczyzny i kobiety, oddaniem na wyłączność - i tym się różni od oddania się na przykład matki dla dziecka albo lekarza dla chorego. Aby mężczyzna i kobieta oddali się sobie, muszą niejako «podpiąć» poziom fizyczno-psychiczny, na którym przeżywają swoją miłość, pod poziom osobowy, ponieważ dopiero taki zintegrowany, personalistyczny wymiar miłości wyraża prawdziwe oddanie oblubieńcze” (A. Pala, Mistyka św. Jana od Krzyża w filozoficznej koncepcji miłości Karola Wojtyły?, „Logos i Ethos” 2017 nr 1, s. 151).

${ }^{51}$ „Afirmacja mojej osoby, jak i każdej innej staje się warunkiem aktualizacji mojej potencjalności i potencjalności innych" (G. Hołub, Kobiecość i męskość w spetnianiu osoby w ujęciu Karola Wojtyły, w: Wokół antropologii Karola Wojtyły, red. A. Maryniarczyk, P. Sulenta, P. Duma, Lublin 2016, s. 403). 
Miłość jako afirmacja godności osoby jest nierozerwalnie związana z odpowiedzialnością za każdy czyn, którego przedmiotem jest druga osoba $^{52}$. O wadze tego zagadnienia świadczy niewątpliwie już sam tytuł jednej z książek Wojtyły Miłość $i$ odpowiedzialność, która była jego główną pracą z zakresu etyki. Autor pisze w niej: „Im więcej poczucia odpowiedzialności za osobę, tym więcej prawdziwej miłości”" ${ }^{33}$. Rozwijając nieco ten ważny wątek, trzeba zauważyć, że odpowiedzialność w kontekście miłości jest czymś więcej niż omawiana wcześniej odpowiedzialność w kontekście wyłącznie wolności. Nie polega ona bowiem jedynie na ponoszeniu moralnych konsekwencji swoich wolnych czynów, ale także, i to w większym stopniu, na wezwaniu do realizacji czynów dla dobra drugiej osoby. To właśnie dobro osoby kochanej jest tym, co winno leżeć na sercu osobie prawdziwie odpowiedzialnej, ponieważ gdy utraci ona poczucie odpowiedzialności za to dobro, to zacznie tę osobę zaniedbywać - i zacznie ponosić odpowiedzialność za to, czego nie uczyniła, choć powinna. Jednocześnie trzeba dostrzec, że akcentowana przez Wojtyłę odpowiedzialność jest tym, co odnosi miłość do godności - ponieważ wzywa do tego, aby poprzez miłość afirmować godność drugiej osoby. Co ciekawe, taka postawa cechująca się poczuciem odpowiedzialności za osobę stanowi szczególny rodzaj afirmacji drugiego, bowiem osoba wyczulona w ten sposób na godność drugiego nie musi wcale nic wyjątkowego czynić, aby ta druga osoba wiedziała, że jest kochana wystarczy, że przy niej jest na co dzień, że z troską towarzyszy jej w tym, co ją spotyka. Dopiero osoba, która dojrzała do takiej odpowiedzialnej miłości, może być bezinteresownym darem dla drugiej osoby, a jej miłość jest też najwyższą wartością moralną ${ }^{54}$. Miłość odpowiedzialna jest

52 Nakaz respektu dla godności osoby streszcza zasada: persona est affirmanda propter se ipsam (Por. A. Szostek, Rola pojęcia godności w etyce, „Studia Filozoficzne” 1983 nr 8-9, s. 84).

53 Por. K. Wojtyła, Miłość i odpowiedzialność, dz. cyt., s. 117.

54 „Uznanie, iż człowiek spełnia się poprzez bezinteresowny dar z siebie samego, wskazuje na znamienny paradoks wolności. Spełnienie osoby w jej wolności polega bowiem poniekąd na rezygnacji z własnego, wolnego decydowania o sobie; na wolnym «oddaniu» siebie drugiej, umiłowanej osobie. Najgłębszym aktem wolności okazuje się dobrowolne związanie się z drugą sobą, oddanie się jej w miłości" (A. Szostek, Od samostanowienia do daru z siebie i uczestnictwa. O Karola Wojtyły/Jana Pawła II koncepcji wolności, „Nauka” 2005 nr 3, s. 43). 
oczyszczona z nieopanowanych uczuć i pozwala kochać drugą osobę w całej jej prawdzie. Nie kończy się ani pod wpływem przemijania zalet tej osoby, ani ujawniania się z czasem jej wad. Nawet pomimo grzechów tej osoby, taka miłość pozwala kochać ją szczerze, bo ze współczuciem dla jej problemów i ograniczeń - poznawszy wpierw jej absolutną godność ${ }^{55}$.

\section{Podsumowanie}

Relacje zachodzące między godnością, wolnością a miłością w filozofii Karola Wojtyły mają ściśle określony porządek. Przede wszystkim godność jest fundamentem wolności zarówno w sensie aksjologicznym, ponieważ wyznacza pole aksjologiczne dla wolności, jak i w sensie ontologicznym, ponieważ doskonałość bytowania człowieka-osoby jako istoty rozumnej i wolnej (a więc doskonałość, której synonimem jest godność), sprawia, że może on korzystać ze swej wolności. Natomiast powinność moralna, którą człowiek odczytuje dzięki sumieniu, skłania go do wykorzystania swojej wolności, do realizacji tych wartości moralnych, które najlepiej harmonizują z jego godnością. Z kolei związek wolności z miłością polega na tym, że wolność jest niejako drogą dla miłości, ponieważ ją umożliwia - a jednocześnie miłość nadaje sens wolności, a tym samym zabezpiecza ją przed samowolą. Ponadto, to dzięki wolności człowiek jest odpowiedzialny za swoje czyny - odpowiedzialność jest jakby ceną za dar wolności. A zatem człowiek odpowiedzialny to człowiek, który w wolności odpowiada na wymagania, jakie stawia przed nim prawda o ludzkiej godności - odpowiada poprzez afirmację tej godności. Tym samym chroni wolność przed absolutyzacją polegającą na ustanawianiu przez nią samą prawdy o tym, co dobre. Specyfikę relacji godność-wolność-miłość można też scharakteryzować w następujący sposób: tylko wolność, która spełnia się w prawdziwej miłości jest w stanie odpowiedzieć na wymagania, jakie stawia powinność moralna zakorzeniona w obiektywnym dobru osoby, którego wyrazem jest godność.

55 Por. K. Wojtyła, Miłość i odpowiedzialność, dz. cyt., s. 116-120. 


\section{Bibliografia}

Biesaga T., Godność a wolność w antropologii Karola Wojtyly, w: Ku rozumieniu godności człowieka, red. G. Hołub, P. Duchliński, Kraków 2008, s. 65-76 (Studia z Bioetyki, 4).

Galarowicz J., Imię własne człowieka. Klucz do myśli i nauczania Karola Wojtyły - Jana Pawła II, Kraków 1996.

Galarowicz J., Paradoks egzystencji etycznej, t. 5, Kraków 2009 (Studia nad Myślą Jana Pawła II).

Hołub G., Kobiecość i męskość w spetnianiu osoby w ujęciu Karola Wojtyły, w: Wokół antropologii Karola Wojtyly, red. A. Maryniarczyk, P. Sulenta, P. Duma, Lublin 2016, s. 395-406. Jałocho-Palicka M., Dobro izło w dramacie poznania (W kregu inspiracji Karola WojtylyJana Pawła II), „Scripta Philosophica. Zeszyty naukowe doktorantów Wydziału Filozofii KUL" 2 (2013), s. 73-91.

Jan Paweł II, Pamięć i tożsamość. Rozmowy na przełomie tysiącleci, Kraków 2005.

Kant I., Uzasadnienie metafizyki moralności, Kęty 2017.

Pala A., Mistyka św. Jana od Krzyża w filozoficznej koncepcji miłości Karola Wojtyły?, „Logos i Ethos” 2017 nr 1, s. 139-157.

Szostek A., Od samostanowienia do daru z siebie i uczestnictwa. O Karola Wojtyty/Jana Pawła II koncepcji wolności, „Nauka” 2005 nr 3, s. 35-47.

Szostek A., Rola pojęcia godności w etyce, „Studia Filozoficzne” 1983 nr 8-9, s. 76-91.

Wojtyła K., Akt i przeżycie etyczne, w: Wykłady lubelskie, red. T. Styczeń, W. Chudy, J. W. Gałkowski, A. Rodziński, A. Szostek, Lublin 2006, s. 19-73.

Wojtyła K., Dobro i wartość, w: Wykłady lubelskie, red. T. Styczeń, W. Chudy, J. W. Gałkowski, A. Rodziński, A. Szostek, Lublin 2006, s. 75-178.

Wojtyła K., Elementarz etyczny, Lublin 1999.

Wojtyła K., Ewangeliczna zasada naśladowania. Nauka źródeł objawienia a system filozoficzny Maxa Schelera, w: Zagadnienie podmiotu moralności, red. T. Styczeń, J. W. Gałkowski, A. Rodziński, A. Szostek, Lublin 2001, s. 147-158.

Wojtyła K., Miłość i odpowiedzialność, Lublin 2001.

Wojtyła K., Osoba i czyn, w: „Osoba i czyn” oraz inne studia antropologiczne, red. T. Styczeń, W. Chudy, J. W. Gałkowski, A. Rodziński, A. Szostek, Lublin 2000, s. 43-338.

Wojtyła K., Osoba: podmiot i wspólnota, w: „Osoba i czyn” oraz inne studia antropologiczne, red. T. Styczeń, W. Chudy, J. W. Gałkowski, A. Rodziński, A. Szostek, Lublin 2000, s. 317-414. 
Wojtyła K., Osobowa struktura samostanowienia, w: „Osoba i czyn” oraz inne studia antropologiczne, red. T. Styczeń, W. Chudy, J. W. Gałkowski, A. Rodziński, A. Szostek, Lublin 2000, s. 421-432.

Wojtyła K., Podmiotowość i „to, co nieredukowalne” w człowieku, w: „Osoba i czyn” oraz inne studia antropologiczne, red. T. Styczeń, W. Chudy, J. W. Gałkowski, A. Rodziński, A. Szostek, Lublin 2000, s. 433-444.

Wojtyła K., Problem oderwania przeżycia od aktu w etyce na tle pogladów Kanta i Schelera, w: Zagadnienie podmiotu moralności, red. T. Styczeń, J. W. Gałkowski, A. Rodziński, A. Szostek, Lublin 2001, s. 159-180.

Wojtyła K., Rozważania o istocie człowieka, Kraków 1999.

Wojtyła K., Zagadnienie woli w analizie aktu etycznego, w: Zagadnienie podmiotu moralności, red. T. Styczeń, J. W. Gałkowski, A. Rodziński, A. Szostek, Lublin 2001, s. 181200 (Człowiek i Moralność, 2).

Wojtyła K., Znak, któremu sprzeciwiać się będą, Kraków 2005.

\section{Abstrakt \\ Godność-wolność-miłość: struktura dynamizmu życia osobowego człowieka w ujęciu Karola Wojtyły}

Relacje zachodzące między godnością, wolnością a miłością w filozofii Karola Wojtyły mają ściśle określony porządek. Godność jest fundamentem wolności zarówno w sensie aksjologicznym, jak i ontologicznym. Godność wyznacza pole aksjologiczne dla wolności, a także wyraża doskonałość bytowania człowieka-osoby jako istoty rozumnej i wolnej. Kolejna relacja polega na tym, że wolność jest dla miłości, ponieważ dzięki wolności miłość jest możliwa - a jednocześnie miłość zabezpiecza wolność przed samowolą. Wreszcie miłość jest afirmacją godność, ponieważ tylko miłość może w pełni odpowiedzieć na wymagania stawiane przez godność osoby. Zatem porządek omawianych relacji można streścić w następujący sposób: wychodząc od godności, poprzez wolność i miłość, powraca się do godności.

\section{Słowa kluczowe}

Karol Wojtyła, osoba, godność, wolność, miłość 


\section{Abstract \\ Dignity-freedom-love: the structure of dynamism of human personal life in the perspective of Karol Wojtyła}

The relations between dignity, freedom and love in Karol Wojtyła's philosophy have a strictly defined order. Dignity is the foundation of freedom in both an axiological and ontological sense. Dignity sets the axiological field for freedom, and also expresses the perfection of human-person existence as a rational and free being. Another relation is that freedom is for love, because thanks to freedom love is possible - and at the same time love protects freedom against willfulness. Finally, love is an affirmation of dignity - because only love can fully respond to the demands made by a person's dignity. Thus, the order of relations can be summarized as follows: starting from dignity, through freedom and love, we return to dignity.

\section{Keywords}

Karol Wojtyła, person, dignity, freedom, love 